\title{
PENGARUH KUALITAS PELAYANAN DAN NILAI PELANGGAN TERHADAP \\ LOYALITAS PELANGGAN MELALUI KEPUASAN EMOSIONAL PADA PELANGGAN ANNA FACE \& BODY CARE CENTRE SARAWAK
}

\author{
Lyana \\ Fakultas Ekonomi \\ Universitas Sarjanawiyata Tamansiswa Yogyakarta
}

\begin{abstract}
ABSTRAK
Penelitian ini bertujuan untuk menguji signifikansi pengaruh positif kualitas pelayanan terhadap kepuasan emosional. Menguji signifikansi pengaruh positif nilai pelanggan terhadap kepuasan emosional. Menguji signifikansi pengaruh positif kepuasan emosional terhadap. Menguji signifikansi pengaruh positif Kualitas Layanan terhadap loyalitas pelanggan melalui kepuasan emosional sebagai variable intervening. Menguji signifikansi pengaruh positif nilai pelanggan terhadap loyalitas pelanggan melalui kepuasan emosional sebagai variable intervening.

Variabel penelitian ini adalah kualitas pelayanan, nilai pelanggan, kepuasan emosional dan loyalitas pelanggan. Populasi dalam penelitian ini yaitu semua konsumen dari ANNA Face \& Body Care Centre Sarawak yang jumlahnya tidak dapat diketahui, sehingga jumlah sampel penelitian ini 100, dengan metode pengambilan sampel probabilitas sampling dan acidental sampling. Metode pengambilan data menggunakan kuesioner. Teknik analisis yang digunakan adalah jalur path dengan persamaan regresi linier berganda dengan taraf signifikansi $5 \%$.

Hasil penelitian diperoleh persamaan $1 \mathrm{Y}_{1}=0,310 \mathrm{X}_{1}+0,236 \mathrm{X}_{2}$. Kualitas pelayanan mempunyai pengaruh positif dan signifikan terhadap kepuasan emosional. Nilai pelanggan mempunyai pengaruh positif dan signifikan terhadap kepuasan emosional. Kualitas pelayanan dan nilai pelanggan secara simultan berpengaruh terhadap kepuasan emosional. Kepuasan emosional (Y) dipengauhi kualitas pelayanan dan nilai pelanggan sebesar $14,8 \%$. Persamaan 2 diperoleh persamaan regresi $\mathrm{Y}_{2}=$ $0,281 \mathrm{X}_{1}+0,207 \mathrm{X}_{2}+0,338 \mathrm{Y}_{1}$. Kualitas pelayanan mempunyai pengaruh positif dan signifikan terhadap loyalitas pelanggan. Nilai pelanggan mempunyai pengaruh positif dan signifikan terhadap loyalitas pelanggan Kepuasan emosional mempunyai pengaruh positif dan signifikan terhadap loyalitas pelanggan. Kualitas pelayanan, nilai pelanggan dan kepuasan emosional secara simultan berpengaruh terhadap loyalitas pelanggan, Loyalitas pelanggan (Y2) dipengaruhi kualitas pelayanan, nilai pelanggan dan kepuasan emosional sebesar $32,6 \%$. Kepuasan emosional mampu memperkuat secara positif hubungan antara kualitas pelayanan terhadap loyalitas pelanggan. Kepuasan emosional mampu memperkuat secara positif hubungan antara nilai pelanggan terhadap loyalitas pelanggan.
\end{abstract}

\section{Kata Kunci : Kualitas Pelayanan, Nilai Pelanggan, Kepuasan Emosional dan Loyalitas Pelanggan}




\section{PENDAHULUAN}

\section{Latar Belakang Masalah}

Pada kondisi pasar dengan tingkat persaingan yang sangat ketat, loyalitas adalah suatu konsep yang sangat penting. Keberadaan konsumen yang loyal pada suatu merek menjadi sesuatu hal yang sangat berarti bagi perusahaan tersebut untuk bertahan hidup dan upaya mempertahankan konsumen sering menjadi strategi yang jauh lebih efektif daripada upaya menarik pelanggan baru. Loyalitas pelanggan harus dibangun dengan usaha keras dalam bentuk program pemasaran yang customized, terutama dengan menempatkan pelanggan menjadi pusat semua aktivitas perusahaan. Namun untuk mencapainya, sejumlah persoalan multidimensional menghadang. Sebenarnya banyak variabel yang dapat membangun loyalitas salah satunya adalah kepuasan konsumen. Konsumen yang puas, mereka akan cenderung untuk lebih sering memakai barang/jasa dari perusahaan tadi, maka akan mempengaruhi niat untuk membeli ulang dan menjadi pelanggan yang loyal.

Kepuasan konsumen sebagai salah satu variabel anteseden loyalitas, dapat dibangun oleh perceived value dan kualitas layanan. Hal tersebut berdasarkan penelitian McDougall dan Levesque (2000:403) bahwa perceived value signifikan sebagai faktor penentu dari kepuasan konsumen, bahkan sebagai pengaruh yang konsisten dalam kepuasan. Penelitian terbaru Parasuraman dan Grewal (2000:169) mendefinisikan perceived value sebagai suatu konstruk dinamis yang terdiri dari empat tipe nilai yaitu acquisition value, transaction value,in-use value dan redemption value. Kualitas layanan juga dijadikan sebagai variabel penentu kepuasan konsumen (penelitian Gronholdt, Martensen dan Kristensen (2000:510), serta McDougall dan Levesque (2000:394)).

ANNA Face \& Body Care Centre merupakan salah satu usaha yang bergerak dalam bidang kecantikan, yang tidak terlepas dari persaingan diantara pesaing-pesaing di bidang yang sama. Pelayanan jasa yang diberikan ANNA Face \& Body Care Centre semakin beragam dan inovatif, Brand trust dan Loyalitas pelanggan sangat menentukan kualitas pelayanan, yang diberikan dapat sesuai dengan harapan mereka. Mempertahankan pelanggan yang loyal, serta menjaga agar tidak beralih ke klinik sejenis merupakan hal yang penting untuk mengikat pelanggan-pelanggan ANNA Face \& Body Care Centre. Untuk itu perusahaan perlu membangun kualitas layanan, kepuasaan dan nilai pelanggan yang efektif untuk menarik pelanggan baru Dan mempertahankan pelanggan, customer service yang sigap dalam melayani pelanggan, serta jaminan pada resiko yang berdampak terhadap Loyalitas Pelanggan jasa ANNA Face \& Body Care Centre.

Berdasarkan latar belakang di atas, maka penulis tertarik untuk mengadakan peneltian dengan judul :"Pengaruh Kualitas Pelayanan dan Nilai Pelanggan Terhadap Loyalitas Pelanggan Melalui Kepuasan Emosional Pada Pelanggan ANNA Face \& Body Care Centre Sarawak".

\section{Rumusan Masalah}

Dari latar belakang masalah, perumusan dalam penelitian ini adalah sebagai berikut:

a. Apakah kualitas pelayanan berpengaruh positif terhadap kepuasan emosional pada pelanggan ANNA Face \& Body Care Centre Sarawak?

b. Apakah nilai pelanggan berpengaruh positif terhadap kepuasan emosional pada pelanggan ANNA Face \& Body Care Centre Sarawak?

c. Apakah Kepuasan Emosional berpengaruh positif terhadap loyalitas pelanggan pada pelanggan ANNA Face \& Body Care Centre Sarawak?

d. Apakah Kualitas Layanan berpengaruh positif terhadap loyalitas pelanggan melalui kepuasan emosional sebagai variable intervening pada pelanggan ANNA Face \& Body Care Centre Sarawak?

e. Apakah nilai pelanggan berpengaruh positif terhadap loyalitas pelanggan melalui kepuasan emosional sebagai variable intervening pada pelanggan ANNA Face \& Body Care Centre Sarawak? 


\section{Kajian Teori}

\section{a. Kualitas Pelayanan}

Menurut Kotler (2002:83) definisi pelayanan adalah setiap tindakan atau kegiatan yang dapat ditawarkan oleh suatu pihak kepada pihak lain, yang pada dasarnya tidak berwujud dan tidak mengakibatkan kepemilikan apapun. Produksinya dapat dikaitkan atau tidak dikaitkan pada satu produk fisik. Pelayanan merupakan perilaku produsen dalam rangka memenuhi kebutuhan dan keinginan konsumen demi tercapainya kepuasan pada konsumen itu sendiri. Kotler juga mengatakan bahwa perilaku tersebut dapat terjadi pada saat, sebelum dan sesudah terjadinya transaksi. Pada umumnya pelayanan yang bertaraf tinggi akan menghasilkan kepuasan yang tinggi serta pembelian ulang yang lebih sering. Kata kualitas mengandung banyak definisi dan makna, orang yang berbeda akan mengartikannya secara berlainan tetapi dari beberapa definisi yang dapat kita jumpai memiliki beberapa kesamaan walaupun hanya cara penyampaiannya saja biasanya terdapat pada elemen sebagai berikut:

1) Kualitas meliputi usaha memenuhi atau melebihkan harapan pelanggan.

2) Kualitas mencakup produk, jasa, manusia, proses dan lingkungan

3) Kualitas merupakan kondisi yang selalu berubah.

Menurut Parasuraman (2002), kualitas pelayanan dapat diukur dengan indikator adalah:

1) Keandalan (Reliability), yaitu kemampuan untuk memberikan jasa secara tepat waktu (on time), dengan cara yang sama sesuai dengan jadwal yang telah dijanjikan, dan tanpa melakukan kesalahan.

2) Daya Tanggap (Responsiveness), yaitu kemauan atau keinginan para karyawan untuk membantu memberikan jasa yang dibutuhkan konsumen.

3) Jaminan (Assurance), meliputi pengetahuan, kemampuan, keramahan, kesopanan dan sifat dapat dipercaya dari kontak personal untuk menghilangkan sifat keragu-raguan konsumen dan membuat mereka merasa terbebas dari bahaya dan resiko.

4) Empati, yang meliputi sikap kontak personal atau perusahaan untuk memahami kebutuhan dan kesulitan konsumen, komunikasi yang baik, perhatian pribadi, dan kemudahan untuk melakukan komunikasi atau hubungan.

5) Produk-produk fisik (Tangible), tersediannya fasilitas fisik, perlengkapan dan sarana komunikasi, dan lain-lain yang bisa dan harus ada dalam proses jasa.

\section{b. Nilai Pelanggan}

Kotler dan Keller (2009: 14) menyatakan bahwa nilai pelanggan merupakan kombinasi kualitas, pelayanan, harga dari suatu penawaran produk . Nilai terhantar pada pelanggan adalah selisih antara jumlah nilai bagi pelanggan dan jumlah biaya dari pelanggan, dan jumlah nilai bagi pelanggan adalah sekelompok keuntungan yang diharapkan pelanggan dari barang atau jasa tertentu.

Takeuchi dan Quelch (1983) mendeskripsikan faktor-faktor yang mempengaruhi persepsi pelanggan berdasarkan waktu sebelum, pada saat dan sesudah membeli atau mendapatkan suatu pelayanan. Kualitas jasa sangat dipengaruhi oleh persepsi kosumen. Persepsi konsumen lebih mengacu pada perasaan konsumen terhadap jasa yang diterimanya, berdasarkan apa yang dibayangkan dan diterimanya. Bila jasa yang diterima lebih besar dari yang dibayangkan, maka iya akan merasa puas, dan kualitas perusahaan atau produk akan dipersepsikan tinggi, sebaliknya jika merasakan bahwa jasa yang diberikan tidak sesuai yang diharapkan, maka akan terjadi ketidakpuasan dan kualitas jasa dipersepsikan rendah.

Tidak semua persepsi konsumen benar, karena sifatnya sangat subyektif. Oleh karenanya, penyedia jasa harus mengantisipasi dan mengendalikan kemungkinan munculnya persepsi jelek dan keluhan yang seharusnya tidak terjadi. Selain 
itu perusahaan harus peka dan selektif terhadap semua keluhan dan informasi yang disampaikan konsumen. Persepsi konsumen terhadap jasa yang diterimanya dipengaruhi oleh:

1) Cara Penyampaian Jasa (service encounters)

Setiap peristiwa dalam penyampaian jasa, seringkali secara potensial dapat menjadi hal kritis dalam menjalin kepuasan dan loyalitas konsumen. Jika seorang konsumen berinteraksi dengan sebuah perusahaan untuk pertama kalinya, penyampaian jasa pertama kali akan menciptakan kesan pertama (first impression) terhadap organisai. Pada situasi ini, konsumen seringkali belum mempunyai dasar penilaian terhadap organisasi, sehingga interaksi pertama ini akan sangat penting dalam membentuk persepsi konsumen akan kualitas. Ketika seseorang telah mempunyai banyak interaksi dengan sebuah perusahaan, setiap penyampaian jasa sangat penting dalam membentuk citra gabungan (kumulatif/menyeluruh) akan perusahaan dalam ingatan konsumen. Setiap pengalaman positif akan menambah citra gabungan terhadap mutu yang tinggi, sementara interaksi negatif akan membuat konsumen merasa ragu atau tidak pasti akan kualitas perusahaan. Gabungan pengalamanpengalaman tersebut membuat konsumen menerka-nerka kualitas perusahaan dan merasa tidak pasti atas apa yang diharapkan dan diterimanya pada kunjunganberikutnya. Terdapa tiga tipe penyampaian jasa, yaiitu tanpa kontak langsung dengan manusia (remote encounters), kontak dengan manusia (phone encounters), dan cara kontak langsung (face-to-face encounters).

2) Bukti Pelayanan (Evidence of Service)

Ada tiga kategori bukti pelayanan, yaitu yang berhubungan dengan orang (people evidence), misalnya keramahan, pengetahuan, dan kesabaran karyawan; bukti proses (process evidence), misalnya kemampuan perusahaan menyelenggarakan jasa sesuai janjinya; dan bukti fisik (phsyical evidence), misalnya kebersihan dan kenyamanan tempat pelayanan.

3) Image Perusahaan

Image perusahaan adalah persepsi tentang suatu organisasi yang ada daam ingatan konsumen dan dibangun konsumen melalui komunikasi, misalnya iklan, humas, citra fisik, komunikasi dari mulut ke mulut dan oleh pengalaman nyata terhadap perusahaan.

Image perusahaan dapat menjadi penyaring yang mempengaruhi persepsi konsumen atas pelayanan perusahaan. Image positif akan meredamkan kekecewaan atas pelayanan yang jelek, atau konsumen yang mempunyai image sangat positif terhadap perusahaan, ketika mengalami sebuah pengalaman buruk tidak akan menyebabkan akibat fatal terhadap kepuasannya, karena image positif dapat mengurangi pengalaman buruk.

Image negatif akan menyebabkan konsumen cepat marah dan tidak puas apabila terjadi pengalaman buruk dan perlu banyak pengalaman baik untuk mengubah keseluruhan image buruk tersebut.

4) Harga

Harga jasa banyak mempengaruhi persepsi, kualitas, kepuasan dan nilai jasa. Karena jasa tidak berwujud dan sering sulit dinilai sebelum terjadinya pembelian, maka harga seringkali terkaitkan sebagai indikator pendukung yang mempengaruhi harapan dan persepsi jasa. Pada harga yang tinggi, konsumen akan menuntut kualitas yang tinggi dan persepsi mereka akan mempengaruhi ekspektasinya, sebaliknya bila harga rendah, konsumen akan meragukan kemampuan perusahaan untuk menyampaikan jasa.

\section{c. Kepuasan Pelanggan}

Berdasarkan pendapat Irawan (2003), kepuasan pelanggan adalah perasaan puas yang didapatkan oleh pelanggan karena mendapat value dari pemasok, produsen, atau penyedia jasa. Value ini bisa berasal dari produk, pelayanan, sistem atau sesuatu yang bersifat emosi. Pelanggan yang puas adalah 
pelanggan yang akan berbagi kepuasan dengan produsen atau penyedia jasa. Pelanggan yang puas akan berbagi pengalaman pelanggan lain. Bahkan menurut penelitian, pelanggan yang puas akan berbagi pengalaman dengan 3-5 orang kawannya, tetapi jika mereka tidak puas maka mereka akan bercerita kepada 10-15 orang lainnya. Oleh karena itu penting sekali arti dari kepuasan pelanggan untuk referensi bagi perusahaan yang bersangkutan. Berdasarkan studi literature, terdapat lima drive utama kepuasan pelanggan, yaitu:

1) Kualitas Produk

Pelanggan akan merasa puas apabila membeli dan menggunakan produk yang ternyata memiliki kualitas yang baik.

2) Harga

Untuk pelanggan yang sensitif, harga murah adalah sumber kepuasan yang penting karena mereka akan mendapatkan value of money yang tinggi. Bagi pelanggan yang tidak sensitif terhadap harga, komponen harga relatif tidak penting bagi mereka.

3) Kualitas Pelayanan

Kualitas pelayanan sangat tergantung pada tiga hal yaitu sistem, teknologi, dan manusia.

Faktor manusia ini memegang kontribusi sebesar $70 \%$. Tidak mengherankan, kepuasan terhadap kualitas pelayanan biasanya sulit ditiru. Pembentukan sikap dan perilaku yang seiring dengan keinginan perusahaan menciptakan, bukanlah pekerjaan mudah. Pembenahan harus dilakukan mulai dari proses recruitment, pelatihan, budaya kerja, dan hasilnya biasanya baru terlihat setelah 3 tahun.

4) Faktor Emosional

Untuk beberapa produk yang berhubungan dengan gaya hidup, seperti mobil, kosmetik dan pakaian, faktor emosional menempati tempat yang penting untuk menentukan kepuasan pelanggan. Rasa bangga, rasa percaya diri, simbol sukses, bagian dari kelompok orang penting dan sebagainya adalah contoh-contoh nilai emosional yang mendasari kepuasan pelanggan

5) Biaya dan Kemudahan
Pelanggan akan semakin puas apabila relatif murah, nyaman, dan efisien dalam mendapatkan produk atau pelayanan. Peran driver pendorong kepuasan pelanggan tentunya tidak sama antara driver yang satu dengan driver yang lain, masing-masing driver memiliki bobotnya masing-masing sesuai dengan industri perusahaan dan kebutuhan dari para pelanggan yang dimilikinya.

\section{d. Hipotesis}

H1: Terdapat pengaruh positif dan signifikan kualitas layanan terhadap Kepuasan Emosional pada pengguna jasa ANNA Face \& Body Care Centre Sarawak

H2: Terdapat pengaruh positif dan signifikan nilai pelanggan terhadap Kepuasan Emosional pada pengguna jasa ANNA Face \& Body Care Centre Sarawak

H3: Terdapat pengaruh positif dan signifikan kepuasan emosional terhadap loyalitas pada pengguna jasa ANNA Face \& Body Care Centre Sarawak

H4: Terdapat pengaruh positif dan signifikan kualitas layanan terhadap loyalitas pelanggan melalui kepuasan emosional sebagai variable intervening pada pengguna jasa ANNA Face \& Body Care Centre Sarawak

H5: Terdapat pengaruh positif dan signifikan nilai pelanggan terhadap loyalitas pelanggan melalui kepuasan emosional sebagai variable intervening pada pengguna jasa ANNA Face \& Body Care Centre Sarawak

\section{METODE PENELITIAN}

Variabel penelitian ini adalah kualitas pelayanan, nilai pelanggan, kepuasan emosional dan loyalitas pelanggan. Populasi dalam penelitian ini yaitu semua konsumen dari ANNA Face \& Body Care Centre Sarawak yang jumlahnya tidak dapat diketahui, sehingga jumlah sampel penelitian ini 100, dengan metode pengambilan sampel probabilitas sampling dan acidental sampling. Metode pengambilan data menggunakan kuesioner. Teknik analisis 


\section{JURNAL MANAJEMEN VOL. 6 N0. 1 JUNI 2016}

yang digunakan adalah jalur path dengan

taraf signifikansi 5\%.

persamaan regresi linier berganda dengan

HASIL PENELITIAN DAN PEMBAHASAN

A. Deskriptif Variabel Penelitian

a. Variabel Kualitas Pelayanan

Tabel 1

Data Variabel Kualitas Pelayanan

\begin{tabular}{|c|c|c|c|}
\hline Interval & Kategori & Jumlah & Persentase (\%) \\
\hline $5-9$ & $\begin{array}{c}\text { Sangat Tidak } \\
\text { Setuju }\end{array}$ & 0 & 0 \\
\hline$>9-13$ & Tidak Setuju & 0 & 0 \\
\hline$>13-17$ & Netral & 11 & 11 \\
\hline$>17-21$ & Setuju & 69 & 69 \\
\hline$>21-25$ & Sangat Setuju & 20 & 20 \\
\hline \multicolumn{2}{|c|}{ Jumlah } & 100 & 100 \\
\hline
\end{tabular}

Sumber : Data Primer Diolah, 2016

Berdasarkan data diatas menunjukkan bahwa sebagian besar responden menyatakan setuju (69\%), maksudnya kualitas pelayanan

\section{b. Variabel Nilai Pelanggan}

Tabel 2

Data Variabel Nilai Pelanggan

\begin{tabular}{|c|c|c|c|}
\hline Interval & Kategori & Jumlah & Persentase (\%) \\
\hline $5-9$ & $\begin{array}{c}\text { Sangat Tidak } \\
\text { Setuju }\end{array}$ & 0 & 0 \\
\hline$>9-13$ & Tidak Setuju & 1 & 1 \\
\hline$>13-17$ & Netral & 16 & 16 \\
\hline$>17-21$ & Setuju & 61 & 61 \\
\hline$>21-25$ & Sangat Setuju & 22 & 22 \\
\hline \multicolumn{2}{|c|}{ Jumlah } & 100 & 100 \\
\hline
\end{tabular}

Sumber : Data Primer Diolah, 2016

Berdasarkan data diatas menunjukkan bahwa sebagian besar responden menyatakan ANNA Face \& Body Care Centre Sarawak dalam kategori sudah baik. di ANNA Face \& Body Care Centre Sarawak dalam kategori sudah baik. setuju (61\%), maksudnya nilai pelanggan di

\section{c. Variabel Kepuasan Emosional}

Tabel 3

Data Variabel Kepuasan Emosional

\begin{tabular}{|c|c|c|c|}
\hline Interval & Kategori & Jumlah & Persentase (\%) \\
\hline $5-9$ & $\begin{array}{c}\text { Sangat Tidak } \\
\text { Setuju }\end{array}$ & 0 & 0 \\
\hline$>9-13$ & Tidak Setuju & 0 & 0 \\
\hline
\end{tabular}




\section{JURNAL MANAJEMEN VOL. 6 N0. 1 JUNI 2016}

\begin{tabular}{|c|c|c|c|}
\hline$>13-17$ & Netral & 12 & 12 \\
\hline$>17-21$ & Setuju & 58 & 58 \\
\hline$>21-25$ & Sangat Setuju & 31 & 31 \\
\hline \multicolumn{2}{|c|}{ Jumlah } & 100 & 100 \\
\hline
\end{tabular}

Sumber : Data Primer Diolah, 2016

Berdasarkan data diatas menunjukkan bahwa sebagian besar responden menyatakan setuju (58\%), maksudnya kepuasan emosional di ANNA Face \& Body Care Centre Sarawak dalam kategori sudah puas.

\section{d. Variabel Loyalitas Pelanggan}

Tabel 4

Data Variabel Loyalitas Pelanggan

\begin{tabular}{|c|c|c|c|}
\hline Interval & Kategori & Jumlah & Persentase (\%) \\
\hline $5-9$ & $\begin{array}{c}\text { Sangat Tidak } \\
\text { Setuju }\end{array}$ & 0 & 0 \\
\hline$>9-13$ & Tidak Setuju & 0 & 0 \\
\hline$>13-17$ & Netral & 5 & 5 \\
\hline$>17-21$ & Setuju & 62 & 62 \\
\hline$>21-25$ & Sangat Setuju & 33 & 33 \\
\hline \multicolumn{2}{|c|}{ Jumlah } & 100 & 100 \\
\hline
\end{tabular}

Sumber : Data Primer Diolah, 2016

Berdasarkan data diatas menunjukkan bahwa sebagian besar responden menyatakan setuju (62\%), maksudnya loyalitas pelanggan

\section{B. Analisis Data}

1. Uji Asumsi Klasik

a. Uji Normalitas di ANNA Face \& Body Care Centre Sarawak dalam kategori sudah loyal.

Tabel 5.

Hasil Uji Normalitas

\begin{tabular}{|ll|r|}
\hline & & $\begin{array}{r}\text { Unstandardiz } \\
\text { ed Residual }\end{array}$ \\
\hline N & Mean & 100 \\
Normal Parameters & a,b &, 0000000 \\
& Std. Deviation & 1,69876658 \\
Most Extreme & Absolute &, 072 \\
Differences & Positive &, 053 \\
& Negative &,- 072 \\
Kolmogorov-Smirnov Z & &, 716 \\
Asymp. Sig. (2-tailed) & &, 684 \\
\hline
\end{tabular}

a. Test distribution is Normal.

b. Calculated from data.

Sumber: Data diolah, 2016

Tabel 4.14. menunjukkan bahwa nilai Kolmogrov-Smirnov Z sebesar 0,716 dan nilai Asymp. Sig. (2-tailed) sebesar 0,684 yang diperoleh model regresi lebih dari $\alpha$ $(0,05)(0,684>0,05)$, berarti berdistribusi normal 
.b. Uji Multikolinearitas

Tabel 6

Hasil Uji Multikolinieritas

\begin{tabular}{|cl|r|r|}
\hline \multicolumn{2}{|c|}{ Model } & \multicolumn{2}{|c|}{ Collinearity Statistics } \\
\cline { 3 - 4 } & & Tolerance & \multicolumn{1}{c|}{ VIF } \\
\hline 1 & (Constant) & & \\
& Kualitas Pelayanan &, 890 & 1,124 \\
& Nilai Pelanggan &, 930 & 1,075 \\
& Kepuasan Emosional &, 835 & 1,198 \\
\hline
\end{tabular}

Sumber: Data diolah, 2016

Tujuan uji multikolinieritas adalah untuk menguji apakah pada model regresi di atas ditemukan adanya korelasi yang kuat antar variabel independen atau bebas yaitu kualitas pelayanan, nilai pelanggan dan

tersebut, dapat dilihat nilai VIF semua variabel memiliki nilai $\mathrm{VIF}<10$, sehingga model regresi tersebut di atas tidak terjadi multikolinieritas sehingga model regresinya dapat digunakan.

kepuasan emosional. Dari hasil olah data

\section{c. Uji Heteroskedastisitas}

Tabel 7

Nilai Uji Heteroskedastisitas

\begin{tabular}{|l|r|r|c|l|}
\hline Variabel bebas & Sig & $\alpha$ & $\begin{array}{c}\text { Keterang } \\
\text { an }\end{array}$ & Kesimpulan \\
\hline Kualitas pelayanan & 0,0 & 0, & $\begin{array}{c}\text { Tidak } \\
\text { Signifika } \\
n\end{array}$ & Tidak Terjadi \\
& 85 & 05 & $\begin{array}{l}\text { Heteroskedastisi } \\
\text { tas }\end{array}$ \\
\hline Nilai pelanggan & 0,3 & 0, & $\begin{array}{c}\text { Tidak } \\
\text { Signifika } \\
\text { Tidak Terjadi }\end{array}$ & $\begin{array}{l}\text { Heteroskedastisi } \\
\text { tas }\end{array}$ \\
\hline $\begin{array}{l}\text { Kepuasan } \\
\text { emosional }\end{array}$ & 02 & 05 & & $\begin{array}{c}\text { Tidak Terjadi } \\
\end{array}$ \\
& 56 & 05 & $\begin{array}{c}\text { Tidak } \\
\text { Signifika } \\
\mathrm{n}\end{array}$ & $\begin{array}{l}\text { Heteroskedastisi } \\
\text { tas }\end{array}$ \\
\hline
\end{tabular}

Sumber: Data diolah, 2016

Dari tabel diatas diperoleh bahwa seluruh variabel bebas mempunyai nilai probabilitas yang lebih besar dari taraf signifikan 0,05 , sehingga dapat disimpulkan bahwa dalam model regresi tersebut tidak terjadi Heteroskedastisitas 


\section{Analisis Regresi Berganda Persamaan 1}

a. Persamaan Regresi Berganda 1

Tabel 8

Hasil Pengujian Regresi Berganda Persamaan 1

\begin{tabular}{|ll|r|}
\hline Model & \multicolumn{2}{|c|}{$\begin{array}{c}\text { Standardized } \\
\text { Coefficients }\end{array}$} \\
\cline { 3 - 3 } & & \multicolumn{1}{|c|}{ Beta } \\
\hline 1 & (Constant) &, 310 \\
& Kualitas Pelayanan &, 236 \\
\hline
\end{tabular}

Sumber: Data diolah, 2016

$\mathrm{Y}_{1}=0,310 \mathrm{X}_{1}+\mathbf{0 , 2 3 6} \mathrm{X}_{2}$

Koefisien beta kualitas pelayanan positif, hal ini menunjukkan bahwa setiap kenaikan kualitas pelayanan atau semakin tinggi kualitas pelayanan, maka semakin meningkatkan kepuasan emosional.

Koefisien beta nilai pelanggan positif, hal ini menunjukkan bahwa setiap kenaikan nilai pelanggan, maka semakin meningkatkan kepuasan emosional. Uji t

Tabel 9

Hasil Uji t Persamaan 1

\begin{tabular}{|rl|r|r|}
\hline Model & & \multicolumn{2}{|c|}{} \\
& & $\mathrm{t}$ & \multicolumn{1}{|c|}{ Sig. } \\
\hline 1 & (Constant) & 4,860 &, 000 \\
& Kualitas Pelayanan & 3,332 &, 001 \\
& Nilai Pelanggan & 2,530 &, 013 \\
\hline
\end{tabular}

Sumber: Data diolah, 2016

Dari hasil oleh data di atas diketahui t-hitung masing - masing variabel adalah :

1) Variabel kualitas pelayanan t-hitung lebih besar dari t-tabel $(3,332>1,980)$ dengan probabilitas $(0,001)$ lebih kecil dari taraf signifikan 0,05, dengan demikian Ho ditolak dan Ha diterima, artinya variabel kualitas pelayanan mempunyai pengaruh positif dan signifikan terhadap kepuasan emosional.
2) Variabel nilai pelanggan t-hitung lebih besar dari t-tabel $(2,530>1,980)$ dengan probabilitas $(0,013)$ lebih kecil dari taraf signifikan 0,05, dengan demikian Ho ditolak dan Ha diterima, artinya variabel nilai pelanggan mempunyai pengaruh positif dan signifikan terhadap kepuasan emosional.

\section{Uji F}

Tabel 10

Hasil Nilai Uji-F Persamaan 1

\begin{tabular}{|cl|c|c|}
\hline Model & & $\mathrm{F}$ & Sig. \\
\hline 1 & $\begin{array}{l}\text { Regression } \\
\text { Residual } \\
\text { Total }\end{array}$ & 9,595 & \\
& & & \\
\hline
\end{tabular}

Sumber: Data diolah, 2016 


\section{JURNAL MANAJEMEN VOL. 6 N0. 1 JUNI 2016}

Dari hasil pengolahan data di atas diketahui bahwa nilai F-hitung adalah 9,595. Dengan nilai signifikan sebesar 0,000 , dan nilai F-tabel adalah 3,1751. Dengan demikian dapat disimpulkan bahwa F-hitung $>$ F-tabel dengan tingkat signifikan $0,000<0,05$ $(\mathrm{p}<0,05)$, maka Ho ditolak dan Ha diterima berarti variabel-variabel kualitas pelayanan dan nilai pelanggan secara simultan berpengaruh terhadap kepuasan emosional.

\section{d. Koefisien Determinasi}

\section{Tabel 11}

Hasil Analisis Uji Koefisien Determinasi $\left(\mathbf{R}^{2}\right)$ Persamaan 1

\begin{tabular}{|c|c|r|r|r|}
\hline Model & $\mathrm{R}$ & $\begin{array}{c}\mathrm{R} \\
\text { Square }\end{array}$ & $\begin{array}{c}\text { Adjusted } \mathrm{R} \\
\text { Square }\end{array}$ & $\begin{array}{r}\text { Std. Error of } \\
\text { the Estimate }\end{array}$ \\
\hline 1 &, $406^{\mathrm{a}}$ &, 165 &, 148 & 1,87525 \\
\hline
\end{tabular}

a. Predictors: (Constant), Nilai Pelanggan, Kualitas Pelayanan

a. Predictors: (Constant), Pelatihan, Program K3

Sumber: Data diolah, 2016

Dari perhitungan di atas diperoleh nilai Adjusted $\mathrm{R}^{2}=0,148$ atau $14,8 \%$, hal ini menunjukkan bahwa variasi kepusan emosional (Y) yang dapat dijelaskan variabel kualitas pelayanan dan nilai pelanggan sebesar $14,8 \%$. Sedangkan sisanya sebesar $85,2 \%$ dipengaruhi faktor lain diluar persamaan diatas.

\section{Analisis Regresi Berganda Persamaan 2}

\section{a. Persamaan Regresi Berganda 2}

Tabel 12

Hasil Pengujian Regresi Berganda Persamaan 2

\begin{tabular}{|ll|r|}
\hline Model & \multicolumn{2}{|c|}{$\begin{array}{c}\text { Standardized } \\
\text { Coefficients }\end{array}$} \\
\cline { 3 - 3 } & & \multicolumn{2}{|c|}{ Beta } \\
\hline 1 & (Constant) &, 281 \\
& Kualitas Pelayanan &, 207 \\
& Nilai Pelanggan &, 338 \\
& Kepuasan Emosional & \multicolumn{2}{|c|}{} \\
&
\end{tabular}

Sumber: Data diolah, 2016

$Y_{2}=0,281 X_{1}+0,207 X_{2}+0,338 Y_{1}$

Koefisien beta kualitas pelayanan positif, hal ini menunjukkan bahwa setiap kenaikan kualitas pelayanan atau semakin baik kualitas pelayanan, maka semakin meningkatkan loyalitas pelanggan. Koefisien beta nilai pelanggan positif, hal ini menunjukkan bahwa setiap kenaikan nilai pelanggan atau semakin baik nilai pelanggan, maka semakin meningkatkan loyalitas pelanggan. Koefisien beta kepuasn emosional positif, hal ini menunjukkan bahwa setiap kenaikan kepuasan emosional, maka semakin meningkatkan loyalitas pelanggan. 


\section{b. Uji t}

Tabel 13

Hasil Uji t Persamaan 2

\begin{tabular}{|rl|r|r|}
\hline Model & & \multicolumn{2}{|c|}{ Sig. } \\
\hline 1 & & $\mathrm{t}$ &, 042 \\
& & & \multicolumn{1}{c|}{ S } \\
& & 2,057 &, 002 \\
& Kualitas Pelayanan & 3,209 &, 018 \\
& Nilai Pelanggan & 2,414 &, 000 \\
\hline
\end{tabular}

Sumber: Data diolah, 2016

Dari hasil oleh data di atas diketahui t-hitung masing - masing variabel adalah :

1) Variabel kualitas pelayanan t-hitung lebih besar dari t-tabel $(3,209>1,980)$ dengan probabilitas $(0,002)$ lebih kecil dari taraf signifikan 0,05, dengan demikian Ho ditolak dan Ha diterima, artinya variabel kualitas pelayanan mempunyai pengaruh positif dan signifikan terhadap loyalitas pelanggan.

2) Variabel nilai pelanggan t-hitung lebih besar dari t-tabel $(2,414>1,980)$ dengan probabilitas $(0,018)$ lebih kecil dari taraf signifikan 0,05, dengan demikian Ho ditolak dan Ha diterima, artinya variabel nilai pelanggan mempunyai pengaruh positif dan signifikan terhadap loyalitas pelanggan.

3) Variabel kepuasan emosional t-hitung lebih besar dari t-tabel $(3,745>1,980)$ dengan probabilitas $(0,000)$ lebih kecil dari taraf signifikan 0,05, dengan demikian Ho ditolak dan Ha diterima, artinya variabel kepuasan emosional mempunyai pengaruh positif dan signifikan terhadap loyalitas pelanggan

c. Uji F

Tabel 14

Hasil Nilai Uji-F Persamaan 2

\begin{tabular}{|ll|c|c|}
\hline Model & & $\mathrm{F}$ & Sig. \\
\hline 1 & Regression & 16,946 &, $000^{\mathrm{a}}$ \\
& Residual & & \\
& Total & & \\
\hline
\end{tabular}

Sumber: Data diolah, 2016

Dari hasil pengolahan data di atas diketahui bahwa nilai F-hitung adalah 16,946. Dengan nilai signifikan sebesar 0,000, dan nilai F-tabel adalah 3,1751. Dengan demikian dapat disimpulkan bahwa F-hitung $>$ F-tabel dengan tingkat signifikan $0,000<0,05(\mathrm{p}<0,05)$, maka Ho ditolak dan Ha diterima berarti variabel-variabel kualitas pelayanan, nilai pelanggan dan kepuasan emosional secara simultan berpengaruh terhadap loyalitas pelanggan.

\section{d. Koefisien Determinasi}

Tabel 15

Hasil Analisis Uji Koefisien Determinasi $\left(\mathbf{R}^{2}\right)$ Persamaan 2

\begin{tabular}{|c|r|r|r|r|}
\hline Model & $\mathrm{R}$ & $\mathrm{R}$ Square & $\begin{array}{c}\text { Adjusted } \mathrm{R} \\
\text { Square }\end{array}$ & $\begin{array}{c}\text { Std. Error of } \\
\text { the Estimate }\end{array}$ \\
\hline 1 &, $588^{\mathrm{a}}$ &, 346 &, 326 & 1,72511 \\
\hline
\end{tabular}

Sumber: Data diolah, 2016 

Dari perhitungan di atas diperoleh nilai Adjusted $\mathrm{R}^{2}=0,326$ atau 32,6\%, hal ini menunjukkan bahwa variasi loyalitas pelanggan $(\mathrm{Y})$ yang dapat dijelaskan variabel kualitas pelayanan, nilai pelanggan dan kepuasan emosional sebesar 32,6\%. Sedangkan sisanya sebesar $67,4 \%$ dipengaruhi faktor lain.

a. Pengaruh kualitas pelayanan terhadap loyalitas pelanggan dengan variabel intervening kepuasan emosional

Besarnya pengaruh langsung $\mathbf{X}_{\mathbf{1}}$ (kualitas pelayanan) terhadap $\mathbf{Y}_{\mathbf{2}}$ (loyalitas pelanggan) sebesar 0,281, sedangkan pengaruh langsung kepuasan emosional terhadap loyalitas pelanggan sebesar 0,338. Besarnya pengaruh tidak langsung diperoleh dengan perkalian $0,281 \times 0,338=$ 0,095, sehingga dapat disimpulkan bahwa ada pengaruh tidak langsung sebesar 0,095. Hal ini dapat disimpulkan bahwa kepuasan emosional mampu memperkuat secara positif hubungan antara kualitas pelayanan terhadap loyalitas pelanggan.

b. Pengaruh nilai pelanggan terhadap loyalitas pelanggan dengan variabel intervening kepuasan emosional

Besarnya pengaruh langsung $\mathbf{X}_{\mathbf{2}}$ (nilai pelanggan) terhadap $\mathbf{Y}_{\mathbf{2}}$ (loyalitas pelanggan) sebesar 0,207, sedangkan pengaruh langsung kepuasan emosional terhadap loyalitas pelanggan sebesar 0,338. Besarnya pengaruh tidak langsung diperoleh dengan perkalian $0,207 \times 0,338=$ 0,07, sehingga dapat disimpulkan bahwa ada pengaruh tidak langsung sebesar 0,07. Hal ini dapat disimpulkan bahwa kepuasan emosional mampu memperkuat secara positif hubungan antara nilai pelanggan terhadap loyalitas pelanggan.

Dari data di atas yaitu diketahui $\mathrm{R}^{2}=$ 0,148 dan $\mathrm{R}_{2}^{2}=0,326$, maka dapat dihitung nilai koefisien determinasi total dengan rumus sebagai berikut:

$$
\begin{array}{ll}
\mathrm{R}_{\mathrm{t}}^{2}=1-[(1-0,148)(1-0,326)] & \mathrm{R}_{\mathrm{t}}^{2}=1-\left[\left(1-\mathrm{R}_{1}^{2}\right)\left(1-\mathrm{R}_{2}^{2}\right)\right] \\
\mathrm{R}_{\mathrm{t}}^{2}=1-0,574 & \\
\mathrm{R}_{\mathrm{t}}^{2}=0,426 &
\end{array}
$$

Koefisien determinasi total $\left(\mathrm{R}_{\mathrm{t}}^{2}\right)$ lebih besar $\mathrm{R}_{1}^{2}$ maupun $\mathrm{R}_{2}^{2}$, sehingga dapat disimpulkan bahwa kepuasan emosional mampu memperkuat secara positif hubungan kualitas pelayanan terhadap loyalitas pelanggan, maupun nilai pelanggan terhadap loyalitas pelanggan.

\subsection{Pembahasan}

Kualitas layanan berpengaruh positif dan signifikan terhadap kepuasan emosional pada pengguna jasa ANNA Face \& Body Care Centre Sarawak. Hipotesis yang menyatakan Terdapat pengaruh positif Kualitas layanan terhadap Kepuasan Emosional pada pengguna jasa ANNA Face \& Body Care Centre Sarawak, terbukti. Hal ini menunjukkan bahwa apabila kualitas pelayanan semakin meningkat atau semakin baik, maka akan meningkatkan kepuasan emosional pelanggan, sebaliknya apabila kualitas pelayanan semakin menurun atau semakain tidak baik, maka akan menurunkan kepuasan emosional pelanggan. Hasil ini didukung dengan hasil analisis deskriptif bahwa kategori variabel kualitas pelayanan adalah baik. Hal ini menunjukkan bahwa pelayanan di ANNA Face \& Body Care Centre Sarawak sudah cepat dalam merespon pelanggan, karyawan dapat menangani setiap keluhan dengan cepat dan tepat, informasi yang diberikan selalu tepat dan up date, karyawan selalu bertanggung jawab terhadap pekerjaan dan tata letak/ruang ANNA Face \& Body Care Centre rapi dan nyaman, serta peralatan kecantikan yang digunakannya lengkap. Hal ini didukung peneliti terdahulu Made Irvan Hilmawan dan Alit Suryani (2013) yang menyatakan bahwa kualitas layanan berpengaruh positif dan signifikan terhadap kepuasan emosional. 
Nilai pelanggan berpengaruh positif dan signifikan terhadap kepuasan emosional pada pengguna jasa ANNA Face \& Body Care Centre Sarawak. Hipotesis yang menyatakan Terdapat pengaruh positif nilai pelanggan terhadap kepuasan emosional pada pengguna jasa ANNA Face \& Body Care Centre Sarawak, terbukti. Hal ini menunjukkan bahwa apabila nilai pelanggan semakin meningkat atau semakin baik, maka akan meningkatkan kepuasan emosional pelanggan, sebaliknya apabila nilai pelanggan semakin menurun atau semakain tidak baik, maka akan menurunkan kepuasan emosional pelanggan. Hasil ini didukung dengan hasil analisis deskriptif bahwa kategori variabel nilai pelanggan adalah kategori baik. Hal ini menunjukkan bahwa di ANNA Face \& Body Care Centre Sarawak waktu dan jam layanan terjadwal dengan baik, produk ANNA Face \& Body Care Centre Sarawak mudah digunakan dan mudah memperolehnya, jaminan Produk dan layanan diperhatikan, Produk ANNA Face \& Body Care Centre mempunyai citra yang baik dimata konsumen dan biaya dengan manfaat dari jasa yang ditawarkan sudah sesuai. Hal ini didukung peneliti terdahulu Woro Mardikati dan Naila Farida (2013) yang menyatakan bahwa nilai pelanggan berpengaruh positif dan signifikan terhadap kepuasan konsumen.

Kepuasan emosional berpengaruh positif dan signifikan terhadap loyalitas pelanggan pada pengguna jasa ANNA Face \& Body Care Centre Sarawak. Hipotesis yang menyatakan terdapat pengaruh positif Kepuasan Emosional terhadap loyalitas pelanggan pada pengguna jasa ANNA Face \& Body Care Centre Sarawak, terbukti. Hal ini menunjukkan bahwa apabila kepuasan emosional semakin meningkat atau semakin baik, maka akan meningkatkan loyalitas pelanggan, sebaliknya apabila kepuasan emosional semakin menurun atau semakain tidak baik, maka akan menurunkan loyalitas pelanggan. Hasil ini didukung dengan hasil analisis deskriptif bahwa kategori variabel kepuasan emosional adalah kategori baik. Hal ini menunjukkan bahwa di ANNA Face \& Body Care Centre Sarawak pelanggan merasa senang dengan jasa yang ditawarkan, kualitas pelayanan sudah sesuai dengan tarif yang dibayarkan, pelayanan sudah sesuai dengan yang diharapkan pelangan, dan konsumen percaya dengan pelayanan ANNA Face \& Body Care Centre. Hal ini didukung peneliti terdahulu Made Irvan Hilmawan dan Alit Suryani (2013) yang menyatakan bahwa kepuasan emosional berpengaruh positif dan signifikan terhadap loyalitas pelanggan.

Kualitas pelayanan berpengaruh positif dan signifikan terhadap loyalitas pelanggan pada pengguna jasa ANNA Face \& Body Care Centre Sarawak. Hipotesis yang menyatakan Terdapat pengaruh positif kualitas pelayanan terhadap loyalitas pelanggan pada pengguna jasa ANNA Face \& Body Care Centre Sarawak, terbukti. Hal ini menunjukkan bahwa apabila kualitas pelayanan semakin meningkat atau semakin baik, maka akan meningkatkan loyalitas pelanggan, sebaliknya apabila kualitas pelayanan semakin menurun atau semakain tidak baik, maka akan menurunkan loyalitas pelanggan. Hal ini didukung peneliti terdahulu Partua Pramana Hamonangan Sinaga (2010) yang menyatakan bahwa kualitas pelayanan berpengaruh positif dan signifikan terhadap loyalitas pelanggan.

Nilai pelanggan berpengaruh positif dan signifikan terhadap loyalitas pelanggan pada pengguna jasa ANNA Face \& Body Care Centre Sarawak. Hipotesis yang menyatakan Terdapat pengaruh positif nilai pelanggan terhadap loyalitas pelanggan pada pengguna jasa ANNA Face \& Body Care Centre Sarawak, terbukti. Hal ini menunjukkan bahwa apabila nilai pelanggan semakin meningkat atau semakin baik, maka akan meningkatkan loyalitas pelanggan, sebaliknya apabila nilai pelanggan semakin menurun atau semakain tidak baik, maka akan menurunkan loyalitas pelanggan. Hal ini didukung peneliti terdahulu Suharto (2014) yang menyatakan bahwa nilai 
pelanggan berpengaruh positif dan signifikan terhadap loyalitas pelanggan.

Ada pengaruh tidak langsung atara kualitas pelayanan dengan loyalitas pelanggan melalui kepuasan emosional sebesar 0,095. Hal ini menunjukkan bahwa kepuasan emosional mampu memperkuat secara positif hubungan antara kualitas pelayanan terhadap loyalitas pelanggan. Semakin baik kualitas pelayanan, semakin meningkatkan kepuasan emosional pelanggan, yang pada akhirnya meningkatkan loyalitas pelanggan. Peningkatan kualitas pelayanan yang diiringi dengan peningkatan kepuasan emosional, mendorong peningkatan loyalitas pelanggan.

Ada pengaruh tidak langsung atara nilai pelanggan dengan loyalitas pelanggan melalui kepuasan emosional sebesar 0,07. Hal ini menunjukkan bahwa kepuasan emosional mampu memperkuat secara positif hubungan antara nilai pelanggan terhadap loyalitas pelanggan. Semakin baik nilai pelanggan, semakin meningkatkan kepuasan emosional pelanggan, yang pada akhirnya meningkatkan loyalitas pelanggan. Peningkatan nilai pelanggan yang diiringi dengan peningkatan kepuasan emosional, mendorong peningkatan loyalitas pelanggan.

\section{SIMPULAN}

1. Hasil analisis data dengan Analisis Regresi Berganda persamaan 1 diperoleh persamaan regresi $\mathbf{Y}_{1}=\mathbf{0 , 3 1 0 X _ { 1 }}+$ $\mathbf{0 , 2 3 6 X _ { 2 }}$

2. Variabel kualitas pelayanan mempunyai pengaruh positif dan signifikan terhadap kepuasan emosional, hal ini ditunjukkan dengan nilai t-hitung lebih besar dari ttabel $(3,332>1,980)$ dengan probabilitas $(0,001)$ lebih kecil dari taraf signifikan 0,05 .

3. Variabel nilai pelanggan mempunyai pengaruh positif dan signifikan terhadap kepuasan emosional, hal ini ditunjukkan dengan nilai t-hitung lebih besar dari ttabel $(2,530>1,980)$ dengan probabilitas
$(0,013)$ lebih kecil dari taraf signifikan 0,05 .

4. Variabel-variabel kualitas pelayanan dan nilai pelanggan secara simultan berpengaruh terhadap kepuasan emosional, hal ini ditunjukkan dengan nilai F-hitung $>$ F-tabel dengan tingkat signifikan $0,000<0,05(\mathrm{p}<0,05)$.

5. Kepuasan emosional (Y) dipengauhi kualitas pelayanan dan nilai pelanggan sebesar $14,8 \%$.

6. Hasil analisis data dengan Analisis Regresi Berganda persamaan 2 diperoleh persamaan regresi $\mathbf{Y}_{2}=\mathbf{0 , 2 8 1 X _ { 1 }}+$

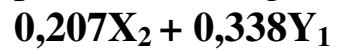

7. Variabel kualitas pelayanan mempunyai pengaruh positif dan signifikan terhadap loyalitas pelanggan, hal ini ditunjukkan dengan nilai t-hitung lebih besar dari ttabel $(3,209>1,980)$ dengan probabilitas $(0,002)$ lebih kecil dari taraf signifikan 0,05 .

8. Variabel nilai pelanggan mempunyai pengaruh positif dan signifikan terhadap loyalitas pelanggan hal ini ditunjukkan dengan nilai $(2,414>1,980)$ dengan probabilitas $(0,018)$ lebih kecil dari taraf signifikan 0,05

9. Variabel kepuasan emosional mempunyai pengaruh positif dan signifikan terhadap loyalitas pelanggan hal ini ditunjukkan dengan nilai t-hitung lebih besar dari ttabel $(3,745>1,980)$ dengan probabilitas $(0,000)$ lebih kecil dari taraf signifikan 0,05 .

10. variabel-variabel kualitas pelayanan, nilai pelanggan dan kepuasan emosional secara simultan berpengaruh terhadap loyalitas pelanggan, hal ini ditunjukkan dengan nilai F-hitung $>$ F-tabel dengan tingkat signifikan $0,000<0,05(\mathrm{p}<0,05)$.

11. Loyalitas pelanggan (Y2) dipengaruhi kualitas pelayanan, nilai pelanggan dan kepuasan emosional sebesar 32,6\%.

12. Ada pengaruh tidak langsung atara kualitas pelayanan dengan loyalitas pelanggan melalui kepuasan emosional sebesar 0,095. Hal ini menunjukkan 


\section{JURNAL MANAJEMEN VOL. 6 N0. 1 JUNI 2016}

bahwa kepuasan emosional mampu memperkuat secara positif hubungan antara kualitas pelayanan terhadap loyalitas pelanggan.

13. Ada pengaruh tidak langsung atara nilai pelanggan dengan loyalitas pelanggan melalui kepuasan emosional sebesar 0,07. Hal ini menunjukkan bahwa kepuasan emosional mampu memperkuat secara positif hubungan antara nilai pelanggan terhadap loyalitas pelanggan.

\section{DAFTAR PUSTAKA}

Alida Palilati, 2007, Pengaruh Nilai Pelanggan, Kepuasan terhadap Loyalitas Nasabah Tabungan Perbankan di Sulawesi Selatan, Universitas Kristen Petra.

Bahri, Dinda Monika Mediana. 2010. "Analisis Pengaruh Nilai Pelanggan, Kualitas Pelayanan Dan Kedekatan Emosional Pada Nasabah Bank BRI Cabang Pattimura Semarang". Fakultas Ekonomi. Universitas Diponegoro. Semarang.

Gale, B. 1994. Managing Customer Value. New York: Prentice The Free Press.

Ghozali, Imam. 2011. Aplikasi Analisis Multivariate dengan Program IBM SPSS 19. Cetakan Ke 5. Semarang : Badan Penerbit Universitas Diponegoro.

Irawan, Handi. 2002. 10 Prinsip Kepuasan Pelanggan. Jakarta: PT Elex Media Komputindo Kelompok Gramedia.

Pahlevi, Rezah. 2014. “Pengaruh Kepuasan, Kepercayaan Dan Harga Terhadap
Loyalitas Konsumen Pada Green Product". Fakultas Ekonomi Dan Bisnis. Universitas Bengkulu. Bengkulu.

Philip Kotler dan Kevin Lane Keller. 2008.

Manajemen Pemasaran. Edisi ke 3.

Diterjemahkan oleh: Bob Sabran. Jakarta:

Erlangga.

Schermerhorn, John R., 1993. Management for Productivity, New York: John Wiley \& Son

Takeuchi dan Quelch. 1983. Quality is More Than Making A Good Produkct. Businnes Review: July-Agustust.

Tjiptono, Fandy. 2005. Manajemen Pemasaran Jasa. Malang: Bayumedia.

Vanessa Gaffar. 2007. Manajemen Bisnis. Bandung: Alfabeta

Wilkie, W.L. 1994. Consumer Behavior, 3th. Ed. New York:John Wily \& Sons

Yesenia dan Edward H Siregar. 2014. "Pengaruh Kualitas Layanan dan Produk terhadap Kepuasan serta Loyalitas Pelanggan Kentucky Fried Chicken di Tangerang Selatan". Jurnal Manajemen dan Organisasi Vol V, No 3. Kampus Darmaga Bogor.

Zeithaml, Valiare A., dan Bitner. 1996. Services Marketing, 6th Edition, Singopore:McGrow Hill. 